Kumawula, Vol. 3, No.2, Agustus 2020, Hal 246 - 255

DOI: https://doi.org/10.24198/kumawula.v3i2.27054

ISSN 2620-844X (online)

Tersedia online di http://jurnal.unpad.ac.id/kumawula/index

\title{
BIMBINGAN TEKNIS TATA NASKAH DINAS SURAT DI KANTOR DESA TARAI BANGUN KECAMATAN TAMBANG KABUPATEN KAMPAR
}

\author{
Sulaiman Zuhdi ${ }^{1^{*}}$, Prihati $^{2}$, Adia Ferizko ${ }^{3}$ \\ Universitas Lancang Kuning, Jalan Yos Sudarso Km 8 Rumbai, Telp (0761) 52658 \\ Program Studi Administrasi Negara, Fakultas Ilmu Administrasi, Universitas Lancang Kuning \\ *sulaiman@unilak.ac.id
}

\begin{abstract}
ABSTRAK
Dalam rangka meningkatkan efisiensi dan perwujudan tertib administrasi penyelenggaraan pemerintahan dan pembangunan, serta peningkatan pelayanan publik maka pemerintah telah menyusun pedoman umum tata naskah dinas yang ditetapkan melalui Peraturan Menteri Dalam Negeri Nomor 54 tahun 2009 yang berlaku dilingkungan pemerintah daerah termasuk pemerintahan desa. Kantor Desa Tarai Bangun merupakan satu kantor pemerintahan desa yang melayani kepentingan umum tidak akan lepas dari kegiatan surat-menyurat. Aktivitas pelayanan kantor desa dalam memberikan pelayanan dituntut untuk dapat bertindak cepat sehingga menghasilkan informasi yang dapat dipergunakan dalam memberikan pelayanan. Namun permasalahannya adalah perangkat desa masih belum mampu memberikan pelayanan yang baik terutama dalam pembuatan naskah dinas surat. Tujuan pengabdian ini untuk memberikan pemahaman dan pengetahuan kepada mitra bgaimana membuat tata naskah dinas surat. Metode yang digunakan dalam bimbingan teknis ini adalah ceramah dan tanya jawab serta praktik langsung dalam pembuatan surat dinas. Hasil yang diharapkan perangkat desa dapat membuat naskah surat dinas yang sesuai dengan peraturan yang berlaku demi terciptanya kelancaran komunikasi tulis yang efektif dan efisien dalam rangka penyelenggaraan pemerintahan dan pembangunan di desa.
\end{abstract}

Kata Kunci : Tata Naskah Dinas, Surat, Perangkat Desa

\begin{abstract}
In order to improve the efficiency and orderly administration of government and development, as well as to improve public services, the government has compiled general guidelines for official script procedures stipulated through the Minister of Domestic Affairs Regulation No. 54 of 2009, which applies to local governments including the village administration. The Tarai Bangun Village Office is a village government office that serves the public interest and cannot be separated from correspondence. Village office service activities in providing services are required to be able to act quickly so as to produce information that can be used in providing services. But the problem is that village officials are not yet able to provide good services, especially in making official letter manuscripts. The purpose of this service is to provide understanding and knowledge to partners in how to make official letter manuscripts. The method used in this technical guidance is lecture and question and answer as well as direct practice in making official letters. The expected outcome is that village officials can draft official letters in accordance with applicable regulations for the creation of effective and efficient written communication in the context of administering governance and development in the village.
\end{abstract}


Keywords: Official Texts, Letters, Village Officials

\section{PENDAHULUAN}

Surat dan naskah memiliki pengertian yang sama, yaitu segala pernyataan tertulis yang digunakan sebagai sarana komunikasi untuk menyampaikan informasi kepada pihak lain. Meskipun demikian, naskah memiliki implikasi jenis yang lebih luas (dalam konteks tata kearsipan) dibandingkan dengan surat. Secara sederhana tata naskah dinas dapat diartikan sebagai alat komunikasi kedinasan dalam bentuk tertulis yang dibuat dan atau dikeluarkan oleh pejabat yang berwenang dilingkungan pemerintah kabupaten/kota dalam rangka penyelenggaraan tugas pemerintahan dan pembangunan di daerah.

Saat ini ketentuan yang mengatur tentang tata naskah dinas yang berlaku dan dijadikan pedoman telah di atur dalam Peraturan Menteri Dalam Negeri Republik Indonesia nomor 54 tahun 2009 pasal 1 "Tata naskah dinas adalah pengelolaan informasi tertulis yang meliputi pengaturan jenis, format, penyiapan, pengamanan, pengabsahan distribusi, dan penyimpanan naskah dinas serta media yang digunakan dalam komunikasi kedinasan”. Berdasarkan pengertian diatas dapat disimpulkan bahwa pengertian tata naskah dinas adalah kegiatan administrasi mengenai informasi tertulis yang dikeluarkan oleh pejabat yang berwenang untuk urusan kedinasan.

Dalam peraturan tersebut tata naskah dinas dibagi kedalam 2 kelompok yaitu :

1. Naskah dinas produk hukum terdiri atas: Peraturan daerah, Peraturan gubernur, Peraturan bersama gubernur dan Keputusan gubernur.

2. Naskah dinas surat terdiri atas: Intruksi, Surat edaran, Surat biasa, Surat keterangan, Surat perintah, Surat izin, Surat perjanjian, Surat perintah tugas, Surat perintah perjalanan dinas, Surat kuas, Surat undangan, Surat keterangan melaksanakan tugas, Surat panggilan, Nota dinas, Nota pengajuan konsep naskah dinas, Lembar disposisi, Telaahan staf, Pengumuman, Laporan, Rekomendasi, Surat pengantar, Telegram, Lembaran daerah, Berita daerah, Berita acara, Notulen, Memo, Daftar hadir, Piagam, Sertifikat dan STTPP.

Selanjutnya dalam Peraturan Gubernur Riau Nomor 39 Tahun 2010 juga diatur Tentang Tata Naskah Dinas di Lingkungan Pemerintah Daerah Provinsi Riau. Dalam peraturan 
tersebut dijelaskan bahwa penyelenggaraan tata naskah dinas surat meliputi antara lain : Pengelolaan surat masuk, Pengelolaan surat keluar, Tingkat keamanan, Kecepatan proses, Penggunaan kertas surat, Pengetikan sarana administrasi dan Warna dan kualitas kertas

Sedangkan prinsip penyelenggaraan naskah dinas harus mencakup :

1. Ketelitian, diselenggarakan secara teliti dan cermat dari bentuk, susunan pengetikan, isi, struktur, kaidah bahasa dan penerapan kaidah ejaan didalam pengetikan.

2. Kejelasan, diselenggarakan dengan memperhatikan kejelasan aspek fisik dan materi dengan mengutamakan metode yang cepat dan tepat.

3. Singkat dan padat diselenggarakan dengan menggunakan bahasa Indonesia yang baik dan benar.

4. Logis dan meyakinkan, diselenggarakan secara runtut dan logis dan meyakinkan serta struktur kalimat harus lengkap dan efektif

Adapun azas-azas yang harus terpenuhi dalam pembuatan naskah dinas surat meliputi:

1. Azas efisiensi dan efektif yaitu penyederhanaan dalam penulisan, penggunaan ruang atau lembar naskah dinas, spesifikasi informasi dan penggunaan bahasa indonesia yang baik dan benar

2. Pembakuan yaitu diproses dan disusun menurut tata cara, bentuk dan jenis yang telah dibakukan

3. Akuntabilitas yaitu tata naskah dinas dipertanggungjawabkan dari segi isi, format prosedur, kearsipan, kewenangan dan keabsahan

4. Keterkaitan yaitu tata naskah dinas diselenggarakan dalam suatu kesatuan sistem (terkait dengan administrasi umum dan unsur administrasi lainnya nomor surat dan subtansi/isi surat)

5. Kecepatan dan ketepatan yaitu naskah dinas diselesaikan tepat waktu dan tepat sasaran, kejelasan redaksional, kemudahan prosedural, kecepatan penyampaian dan distribusi

6. Keamananan yaitu tata naskah dinas aman secara fisik dan subtansi (isi), mulai dari penyusunan, klasifikasi, penyampaian, pemberkasan, kearsipan dan distribusi. 
Fungsi dari surat dinas yaitu sebagai dokumen dan informasi tertulis sebagai bukti surat tertulis atau alat pengingat berkaitan fungsinya dengan arsip, bukti sejarah atas perkembangan instansi, dan pedoman kerja Undang-Undang, Peraturan dan Surat Keputusan yang telah ditetapkan yang merupakan pedoman atau acuan untuk melaksanakan kegiatan administrasi kantor.

Ketatalaksanaan pemerintah merupakan pengaturan tentang cara melaksanakan tugas dan fungsi dalam berbagai bidang kegiatan pemerintahan di lingkungan instansi pemerintah. Salah satu komponen penting dalam ketatalaksanaan pemerintah adalah administrasi umum. Ruang lingkup administrasi umum meliputi tata naskah dinas, penamaan lembaga, singkatan dan akronim, kearsipan, serta tata ruang perkantoran. Tata naskah dinas sebagai salah satu unsur administrasi umum meliputi, antara lain, pengaturan tentang jenis dan penyusunan naskah dinas, penggunaan lambang negara, logo dan cap dinas, penggunaan bahasa Indonesia yang baik dan benar, pengurusan naskah dinas korespondensi, kewenangan, perubahan, pencabutan, pembatalan produk hukum, dan ralat.

Bagi pemerintah desa pelaksanaan tata naskah dinas sangat diperlukan dalam berjalannya sistem kerja. Setiap pekerjaan dan kegiatan kantor memerlukan penyimpanan, pencatatan serta pengolahan surat, baik kedalam maupun keluar dengan sistem tertentu dan dapat dipertanggung jawabkan. Mengingat peranan surat yang begitu penting bagi kehidupan organisasi, maka surat perlu mendapat perhatian khusus sehingga surat dapat mendukung penyelesaian pekerjaan secara efektif dan efisien.

Kantor Desa Tarai Bangun merupakan salah satu kantor pemerintahan desa yang melayani kepentingan umum tidak akan lepas dari kegiatan surat-menyurat. Aktivitas pelayanan kantor desa dalam memberikan pelayanan dituntut untuk dapat bertindak cepat sehingga menghasilkan informasi yang dapat dipergunakan dalam memberikan pelayanan.

Surat dinas adalah sarana yang paling efektif bagi suatu intansi pemerintah untuk berkomunikasi secara tertulis dengan instansi lainnya. Menyusun surat dinas yang baik tidaklah mudah. Sebagai bentuk komunikasi tulisan, surat menuntut penggunaan bahasa yang tidak saja benar menurut tata bahasa dan ejaan, tetapi juga jelas, efektif dan mampu mengungkapkan maksud yang ingin disampaikan oleh instansi pengirimnya. Sebagai bentuk dokumentasi yang otentik, surat dinas sangat mungkin dibaca orang, diperbanyak, dan disimpan dalam jangka waktu yang lama untuk suatu ketika dilihat kembali. Oleh karena itu, bentuk, isi, dan bahasa sebuah surat dinas menjadi suatu hal yang perlu diperhatikan. 
Permasalahan yang ditemui dilapangan adalah masih minimnya pengetahuan dan wawasan yang dimiliki perangkat desa tentang pembuatan tata naskah dinas surat. Hal ini diakui oleh perangkat desayang mengatakan bahwa pemerintah desa belum pernah mendapatkan bimbingan dan pelatihan tentang pembuatan naskah dinas surat, sehingga mereka sering kesulitan dalam pembuatan surat dinas. Selama ini mereka hanya mencontoh dari format yang ada atau meminjam dari pemerintah desa lain. Selain itu, tingkat pendidikan perangkat desa yang masih rendah juga mempengaruhi dalam pelaksaaan tugas-tugas administrasi pemerintahan desa.

\section{METODE PELAKSANAAN}

Kegiatan Pengabdian Kepada Masyarakat ini melibatkan 3 orang dosen dan seluruh perangkat desa yang ada di kantor desa Tarai Bangun Kecamatan Tambang Kabupaten Kampar. Bahan dan peralatan yang digunakan dalam pelaksanaan pengabdian ini meliputi :

1. Modul tata naskah surat dinas. Dengan modul ini peserta pelatihan dipandu untuk dapat dengan mudah memahami materi yang disampaikan.

2. Power point dan LCD untuk menyampaikan materi kepada peserta, power point yang sudah disiapkan agar peserta dapat memperhatikan lebih mudah.

3. Metode yang digunakan dalam pengabdiaan ini berbentuk ceramah dan tanya jawab serta praktik langsung dalam pembuatan surat.

Metode Evaluasi Dilihat dari :

1. Kehadiran dan partisipasi peserta

2. Kuisioner pretest dan postest.

3. Hasil pembuatan surat dinas.

\section{HASIL DAN PEMBAHASAN}

Sesuai tujuan yang ingin dicapai dalam pelaksanaan pengadian kepada masyarakat di Kantor desa Tarai Bangun yaitu :

1. Mitra memiliki pengetahuan tentang bentuk-bentuk naskah dinas surat.

2. Mitra memiliki kesamaan pengertian dan pemahaman dalam pembuatan tata naskah dinas surat di pemerintahan desa.

3. Tercapainya efektivitas dan efisiensi penyelenggaraan tata naskah dinas di pemerintah desa. 
Maka pelaksanaan bimbingan teknis tata naskah dinas surat ini berjalan cukup efektif. Ini terbukti dengan hadirnya seluruh perangkat desa yang diundang serta keaktifan peserta selama kegiatan berlangsung.

Sesuai dengan apa yang telah direncanakan, bimbingan teknis tata naskah dinas surat di kantor desa Tarai Bangun kecamatan Tambang Kabupaten Kampar oleh tim Pengabdian pada Masyarakat ini telah terlaksana selama satu hari. Kegiatan dilaksanakan pada hari Rabu, 19 Juni 2019 dimulai pada jam 09.00 wib sampai dengan jam 13.00 wib. Acara ini sedianya dijadwalkan mulai pada pukul 08.00, namun karena kendala persiapan teknis dan kesiapan peserta, acara baru dapat dimulai pada pukul 09.00 dengan dihadiri oleh 13 orang peserta dari perangkat desa. Acara diawali dengan pembukaan oleh Kepala Desa Tarai Bangun Kecamatan Tambang Kabupaten Kampar Bapak Andra Maistar, S.Sos, yang dilanjutkan dengan sambutan oleh Ketua Tim Pengabdian yaitu Dr. Hj. Prihati M.Si.

\section{Gambar 1. Foto Pembukaan Pengabdian Masyarakat oleh Kepala Desa Tarai Bangun}

Sebelum materi disampaikan oleh nara sumber, terlebih dahulu dilakukan pemberian kuisioner pre test. Tujuannya untuk mengetahui seberapa besar tingkat pemahaman perangkat desa terhadap naskah dinas. Selanjutnya sesi pertama adalah pengenalan maksud dan tujuan serta pemberian materi bimbingan teknis tata naskah dinas surat di Kantor desa Tarai Bangun oleh Sulaiman Zuhdi S.Sos, M.Si. Maksud pemberian bimbingan teknis ini adalah sebagai acuan pengelolaan tata naskah dinas dan acuan pembuatan petunjuk pelaksanaan tata naskah dinas di kantor desa Tarai Bangun Kecamatan Tambang Kabupaten Kampar. Sedangkan tujuannya adalah memperlancar komunikasi tulis baik internal maupun eksternal secara efektif dan efisien dalam penyelenggaraan pemerintahan dan pembangunan. Materi yang disampaikan adalah pengertian naskah dinas, jenis-jenis naskah dinas, dan penyelenggaraan tata naskah dinas. Materi disampaikan selama kurang lebih satu jam dimulai dari jam 09.00 
wib sampai dengan jam 10.00 wib. Penyampaian materi ini diikuti dengan sesi tanya jawab dimana pada sesi ini para peserta mendapatkan kesempatan untuk berdiskusi langsung dengan pemateri. Para peserta terlihat antusias dan aktif mengajukan beberapa pertanyaan kepada pemateri.

Gambar 2. Foto Pemberian kuisioner kepada peserta

Gambar 3. Foto Diskusi dan Tanya jawab 
Pada sesi kedua pemberian materi oleh Adia Ferizko, S.Sos, M.Si. Materi disampaikan selama kurang lebih satu jam dimulai dari jam 10.00 wib sampai dengan jam 11.00 wib. Materi yang disampaikan tentang bentuk dan format naskah dinas surat. Pada sesi ini, pemberi materi mencoba melihat dan membandingkan format naskah dinas surat yang ada di kantor desa Tarai bangun dengan format naskah dinas yang ada dalam Peraturan Gubernur Riau no. 39 tahun 2010. Dari sini dapat dilihat ada sedikit perbedaan dalam format penulisan, karena pemerintah desa masih menggunakan bentuk surat yang lama. Peserta banyak bertanya dan berdiskusi kepada pemateri.

Selanjutnya setelah materi tersampaikan seluruhnya maka para peserta pelatihan di minta untuk membuat satu contoh naskah dinas surat yang dipandu langsung oleh pemateri. Setelah peserta selesai membuat contoh surat dinas maka dicoba untuk dipresentasikan dan didiskusikan. Sesi ini sekaligus menjadi sesi terakhir, ditutup pada pukul 13.00 WIB.

\section{Gambar 4. Foto Latihan Pembuatan Surat Dinas}


Dari hasil pelaksanaan bimbingan teknis tata naskah dinas surat di kantor desa Tarai Bangun Kecamatan Tambang Kabupaten Kampar ini terlihat para peserta sudah cukup mengerti dan memahami tentang tata naskah dinas surat. Ini dapat dilihat dari hasil post test dan praktek langsung cara pembuatan naskah dinas oleh perangkat desa. Pada pidato penutupan kegiatan ini Kepala Desa Tarai Bangun Kecamatan Tambang Kabupaten Kampar menyampaikan terima kasih yang sebesar-besarnya kepada tim pengabdian masyarakat yang telah bersedia melakukan bimbingan teknis tata naskah dinas surat kepada mereka sehingga diharapkan dengan pengetahuan dan pemahaman mereka terhadap naskah dinas surat ini dapat lebih meningkatkan kinerja perangkat desa dalam memberikan pelayanan administrasi dan pembangunan kepada masyarakat.

\section{Gambar 5. Foto Bersama Peserta Pengabdian}




\section{SIMPULAN}

Kegiatan pengabdian masyarakat di kantor desa Tarai Bangun Kecamatan Tambang Kabupaten Kampar tentang bimbingan teknis tata naskah dinas surat secara umum berlangsung dengan cukup baik, hal ini ditunjukkan dengan bertambahnya pengetahuan dan pemahaman perangkat desa tentang pembuatan naskah dinas surat sehingga memberikan dampak yang positif dalam memperlancar komunikasi tulis baik internal maupun eksternal dalam penyelenggaraan pemerintahan dan pembangunan didesa. Dengan adanya acuan pengelolaan tata naskah dinas dan acuan pembuatan petunjuk pelaksanaaan tata naskah dinas di pemerintah desa Tarai Bangun Kecamatan Tambang Kabupaten Kampar maka diharapkan akan tercipta efektivitas dan efisiensi penyelenggaraan tata naskah dinas di pemerintah desa.

\section{DAFTAR PUSTAKA}

Kosasih dan Darma, Y. Aliah. 2011. Menulis Surat Dinas Lengkap. Bandung: CV. Yrama Widya

Nuraida, Ida. Manajemen Administrasi Perkantoran. Yogyakarta:Kanisius, 2012

Rivai, Veithzal. 2005. Manajemen Sumber Daya Manusia untuk Perusahaan dari Teori ke Praktik. Jakarta: PT. Raja Grafindo Persada.

Suryabrata, Sumadi. 2013. Metodelogi Penelitian. Jakarta: PT Raja Grafindo Persada.

Tarigan, Henry Guntur.2008. Menulis Sebagai Suatu Keterampilan. Bandung: Angkasa Bandung

Triharjanto. 2007. Panduan Menulis Surat. Yogyakarta: Siklus

Wursanto, Kearsipan 1. Yogyakarta:Kanisius, 2003

Peraturan Menteri Pendayagunaan Aparatur Negara Dan Reformasi Birokrasi Republik Indonesia Nomor 80 Tahun 2012 Tentang Pedoman Tata Naskah Dinas Instansi Pemerintah

Peraturan Menteri Dalam Negeri Nomor : 3 Tahun 2005 Tentang Jenis dan Kewenangan Penandatanganan Naskah Dinas di Lingkungan Pemerintah Kabupaten/Kota

Peraturan Menteri Dalam Negeri Nomor 54 Tahun 2009 Tentang Tata Naskah Dinas di Lingkungan Pemerintah Daerah

Peraturan Gubernur Riau Nomor: 39 Tahun 2010 Tentang Tata Naskah Dinas di Lingkungan Pemerintah Daerah Provinsi Riau 
Peraturan Bupati Kampar Nomor 38 Tahun 2011 tentang Pedoman Tata Naskah Dinas Dilingkungan Pemerintah Kabupaten Kampar. 